Alma Mater Studiorum - Università di Bologna DEPARTMENT OF ECONOMICS

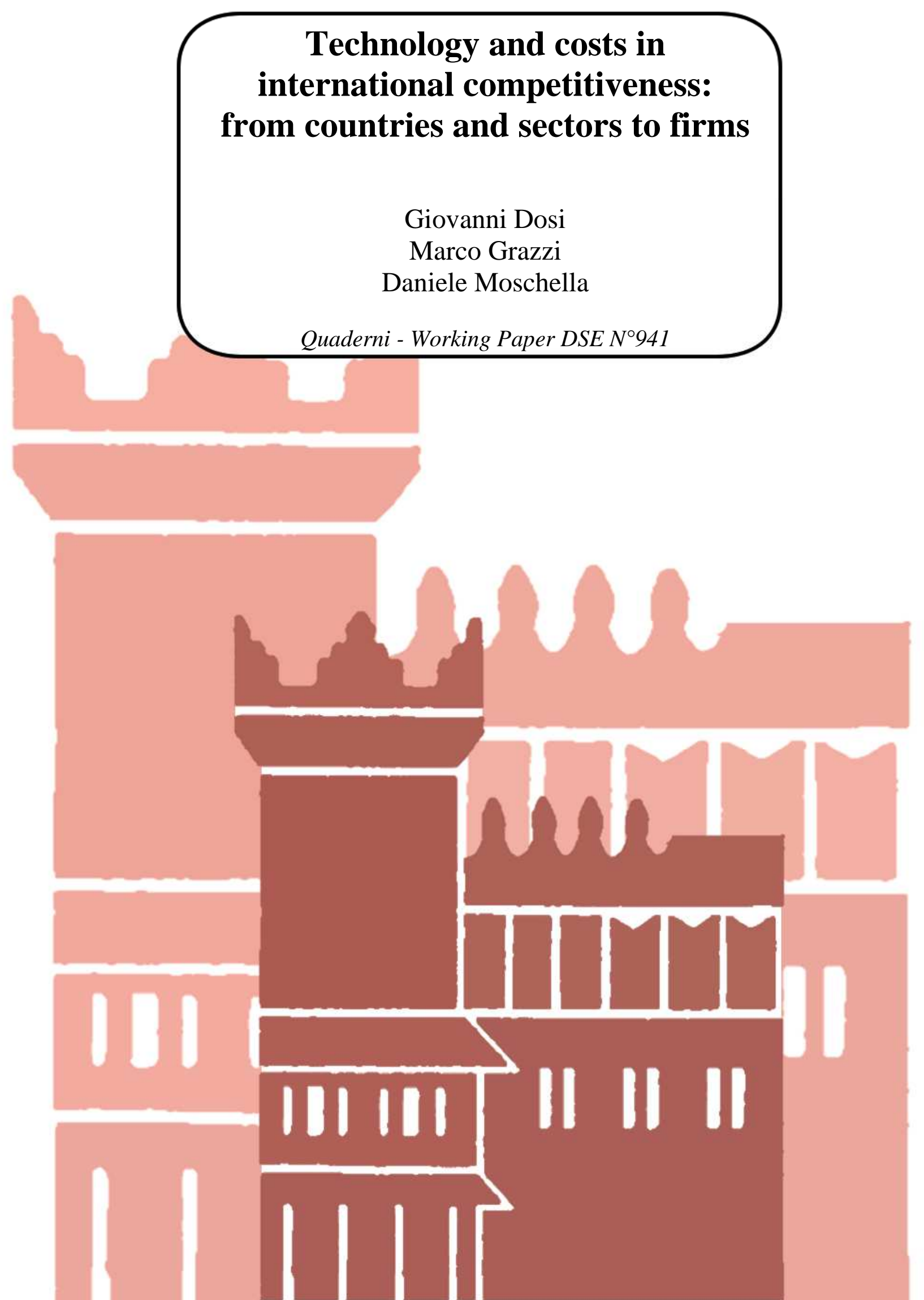




\title{
Technology and costs in international competitiveness: from countries and sectors to firms*
}

\author{
Giovanni Dosi ${ }^{1}$, Marco Grazzi ${ }^{2}$, and Daniele Moschella ${ }^{1}$ \\ ${ }^{1}$ LEM - Scuola Superiore Sant'Anna, Pisa, Italy. \\ ${ }^{2}$ Department of Economics - University of Bologna, Bologna, Italy.
}

May 5, 2014

This paper examines the determinants of international competitiveness at the level of sectors and firms. First, we address the relation between cost-related and technological competition in a sample of fifteen OECD countries. Results suggest that the countries' sectoral market shares are indeed mainly shaped by technological factors (proxied by investment intensity and patents) while cost advantages/disadvantages do not seem to play any significant role. Next, we attempt to identify the underlying dynamics at the firm level. We do that for a single country, Italy, using a large panel of Italian firms, over nearly two decades. Results show that also at micro level in most sectors investments and patents correlate positively both with the probability of being an exporter and with the capacity to acquire and to increase export market shares. The evidence on costs is more mixed. A simple measure like total labour compensation is positively correlated with the probability of being an exporter, while unit labour costs show a negative correlation only in some manufacturing sectors.

KeYwords: Trade Competitiveness, Technological Innovation, Input Costs, Firm behaviour, Technology Gap Theories of Trade.

JEL Classification: D22, F10, F14, F19, L25, O32.

*We thank Davide Castellani, Dietmar Harhoff, Federico Tamagni, Bart Verspagen and I. Kim Wang, for insightful comments. We also thank partecipants at the SEI Doctoral Consortium in Copenhagen (2012), the 8th EMAEE Conference in Nice (2013), the XIV Conference on International Economics in Palma (2013), the IV Conference on Economics of Global Interactions in Bari (2013), the 54th annual SIE Conference in Bologna (2013), the 25th annual EAEPE Conference in Paris (2013), the Copenhagen Conference on Innovation and Entrepreneurship in Skodsborg (2014). We gratefully acknowledge the partial research support by the Institute for New Economic Thinking (Grant 220 to SSSA and Grant 12-00039 to Columbia University). Without the unique support of the Italian Statistical Office, and in particular Roberto Monducci, this all endeavour would not have been possible. The usual disclaimer applies. 


\section{Introduction}

The international competitiveness of a country is of great concern for both economists and policymakers. Indeed, a great deal of interest has gone into the role of cost competition i.e. the ability of a country (firm) to gain export shares by reducing input costs or margins - as compared to technological competition - wherein the source of competitiveness is rather innovation and technical change.

In order to address this question, one angle is from aggregate and sectoral relationships between trading countries, usually trying to estimate the elasticities of export market shares both to costs and to technology variables (Dosi et al., 1990; Fagerberg, 1988; Amendola et al., 1993; Carlin et al., 2001; Laursen and Meliciani, 2010). Revealing as they truly are about the relative importance of cost variables (wages and unit labor costs) as compared to different technological indicators (patents, investments, R\&D, inter-sectoral knowledge flows), these aggregate and sectoral results are likely to hide the vast amount of heterogeneity observed at the firm level. Here, we combine the foregoing approach with a microeconomic one.

The robust evidence about heterogeneity in firms performances along every dimension one is able to observe is extremely robust (see among the others Bartelsman and Doms, 2000; Dosi and Grazzi, 2006; Dosi and Nelson, 2010), and such heterogeneity holds also when only the subset of exporting firms is taken into account (Bernard and Jensen, 2004; Mayer et al., 2011; Greenaway and Kneller, 2007). One consequence is that estimates obtained at the aggregate level might not be isomorphic to what happens at the firm level. Different firms might respond differently to the same shocks (Berman et al., 2012); more generally, the variation between firm-level characteristics offers precious clues on the determinants of trade performance. This is what will be done in the present paper.

At the micro level, the paper addresses the export dynamics of Italian firms. In particular, the focus will be on the role of technology and innovation in explaining both the presence of a firm on the export markets and the dynamics of its market shares. In this respect, to our knowledge, this is the first large scale study on micro export behaviour that considers also the role of innovation.

The paper is organized as follows. Section 2 spells out the framework and the main research questions of the paper. Section 3 presents and describes the available data. Section 4 offers a brief overview of the empirical patterns that hold at the sectoral level. Section 5 presents the empirical methodology and the results related to the analysis of micro data. Section 6 adds further evidence on the role of product and process innovation using data from two waves of CIS surveys. Section 7 concludes. 


\section{Theoretical framework}

Competitiveness is determined by several factors. One is certainly labour costs, the labour being the - relatively more - immobile factor among countries. However, both the aggregate and the micro literatures on international trade have debated the extent to which technological innovation is affecting trade performance, in addition to, or even against changes in labour costs.

At least since the seminal work of Posner (1961), a stream of analysis have been arguing that one of the main sources of (absolute) advantage of a country comes from its relative technological position against its competitors rather than from intersectoral opportunity costs within the same country. The roots of such a perspective date back to 18th and 19th centuries pre-Ricardian or anti-Ricardian theories of trade - including largely forgotten authors like Ferrier and List - and revise in modern technology-gap theories of international trade and related product-cycle views (in addition to Posner, 1961; see Freeman, 1963; Hirsch, 1965; Vernon, 1966; Hufbauer, 1970; Cimoli, 1988 and the discussion in Dosi et al., 1990). In such a perspective, trade flows are primarily driven from sector-specific absolute advantages, in turn stemming primarily from widespread technological asymmetries between countries which relate in first instance to the capability of some countries to produce innovative commodities (i.e. commodities which other countries are not yet capable of producing, irrespective of relative costs) and to use process innovations more efficiently or more quickly thus reducing input coefficients (more in Dosi et al., 1990) ${ }^{1}$.

On the macro and sectoral sides, the empirical findings in Fagerberg (1988), Dosi et al. (1990), Amendola et al. (1993), Amable and Verspagen (1995), and Laursen and Meliciani (2010) have indeed confirmed that international pattern of sectoral absolute advantages/disadvantages are a fundamental determinant of sectoral competitiveness as captured by aggregate and sectoral market shares and their dynamics. And, conversely, that same evidence has largely vindicated Kaldor's original intuition that wage costs at current exchange rates might be irrelevant or even have a perverse long-term impact (Kaldor, 1978).

More recently, on the micro side, the evidence on the determinants of export decision and export intensity has begun to shed light on the fundamental role of product and process innovation driving the export behaviour at the firm level (Wakelin, 1998; Sterlacchini, 1999; Basile, 2001; Castellani and Zanfei, 2007; Caldera, 2010; Becker and Egger, 2013).

In the present framework, the hypothesis that technology matters will be investigated by looking at the relationship between export performance and two leading measures of innovativeness, namely investments and patents. Investments are a proxy for whatever goes under the heading of "embodied technical change" and "process innovation". Patents

\footnotetext{
${ }^{1}$ Differences between the Ricardian and the alternative approaches have also broad implications in terms of economic policy, as argued in Castellacci (2008).
} 
stand mainly for the "disembodied technical change" and "product innovation". Then, we will also employ CIS data to further assess the role of "product" and "process" innovation.

These two forms of innovation can affect the trade performance in several ways. Process innovations involve the acquisition of machineries necessary to produce goods at a lower cost. Product innovation is related to different forms of product differentiation or quality improvement which help firms to gain market shares in a world where consumers have a taste for differentiated and high quality products, or new products altogether.

We start with a reassessment of the relative importance of technology vs. cost-related factors driving international competitiveness on the grounds of a sectoral dataset on most OECD countries over the years 1989-2006.

In the next step we will focus on the disaggregated evidence, for a specific country, Italy. The disaggregation will proceed along two main dimensions. First, the determinants of the presence of firms on the export markets will be analyzed. Many models of international trade (see, among the others, Melitz, 2003) put relative productivity at the forefront in explaining whether a firm will be able to export or not. In this work, the presence of firms in international trade is related both to labour productivity and wage (the two components of unit labour costs) as now standard in the empirical trade literature, and at same time, we will also be considering the role of investments and patents.

Second, and in our view more relevant, the analysis will explicitly address firms' performance and competitiveness in terms of international market shares and growth rates.

\section{Data}

\subsection{Country level data}

We use data for 15 OECD countries from STAN database: Austria, Belgium, Canada, Denmark, Finland, France, Germany, Italy, Japan, Netherlands, Norway, Spain, Sweden, UK and USA ${ }^{2}$. They account on average for $86 \%$ of total dollar exports of all OECD countries.

The STAN database comprise all manufacturing sectors at different levels of aggregation. Our selection, for comparability purposes, contains 11 manufacturing sectors, reported in table 1 , in order to have a nearly complete time series for each sector and each country in the sample.

\subsection{Firm level data}

In order to investigate the sources of firm-level competitiveness several sets of microdata had to be linked together.

\footnotetext{
${ }^{2}$ Data on gross fixed capital formation for Japan come from EU KLEMS database.
} 
Table 1: Industry aggregation

\begin{tabular}{lr}
\hline Sectors & NACE Rev. 1.1 \\
\hline Food, beverages, tobacco & $15-16$ \\
Textiles, wearing, leather & $17-19$ \\
Wood & 20 \\
Paper \& printing & $21-22$ \\
Coke \& petroleum & 23 \\
Chemicals & 24 \\
Rubber and plastics & 25 \\
Non-metallic (mineral products) & 26 \\
Basic metals & 27 \\
Fabricated metal (products) & 28 \\
Machinery & 29 \\
Computing \& electrical (machinery) & $30-33$ \\
Transport equipment & $34-35$ \\
Other Manufacturing & $36-37$ \\
\hline
\end{tabular}

Note: The table lists the sectoral aggregation that will be used in the analysis. NACE codes perfectly matches to the ISIC rev. 3 classification of OECD STAN at this level of aggregation.

The first is MICRO.3, a databank developed within a collaboration between the Italian Statistical Office (ISTAT) and members of the Laboratory of Economics and Management (LEM) of Scuola Superiore Sant'Anna in Pisa. ${ }^{3}$

Micro.3, our main source of firm level variables, is based on the census of Italian firms conducted yearly by ISTAT and contains information on firms with more than 20 employees in all sectors of the economy for the period 1989-2006. Starting in 1998 the census of the whole population of firms only concerns companies with more than 100 employees, whether in the range of employment 20-99, ISTAT directly monitors only a rotating sample which varies every five years. Hence, in order to complete the coverage of firms in that range from 1998 onward, Micro.3 resorts to data from the financial statement that limited liability firms have to disclose, in accordance to Italian law. ${ }^{4}$ In the end, Micro. 3 contains data for 148604 Italian firms, of whom 71437 are active in the Manufacturing sectors. As far as the representativeness of the sample is concerned, Micro.3 covers around $50-60 \%$ of the value added generated by all Italian firms in the manufacturing sectors, NACE Rev. 1.115 to 37 .

Micro.3 has been linked to three other sources of microdata.

The first is the number of patents granted to Italian firms in the US (USPTO) and in Europe (EPO). After the link, a total of 23477 patents turn out to be matched to 1735 firms in Micro.3. This relatively small number reflects the general fact that the percentage of firms which patent in any sector is a small share of the total. Other studies on similar

\footnotetext{
${ }^{3}$ The database has been made available for work after careful censorship of individual information. More detailed information on the database Micro.3 is in Grazzi et al. (2013b).

${ }^{4}$ Limited liability companies (società di capitali) have to provide a copy of their financial statement to the Register of Firms at the local Chamber of Commerce.
} 
database do confirm this trend. Malerba and Orsenigo (1999) employs a dataset which contains 15175 patents application by 3805 firms (Malerba and Orsenigo, 1999, p. 646), while Cefis and Orsenigo (2001), who still consider patents application, rely on 1369 firms (Cefis and Orsenigo, 2001, p. 1142). On the contrary, we consider here only granted patents as a more meaningful proxy of innovation activity. Notice also that the process of linking data on granted patents to other database, such as Micro.3, is usually rather difficult. The classification used by the patent office and that implemented by the national office for structural business statistics are different, hence the comparison and linking of the two database requires some pattern recognition techniques. Indeed, when we refer to empirical work that match patent data to other sources of information the numbers might get even smaller (Scellato, 2007).

The second set of microdata that we link to Micro.3 is COE (Statistiche del Commercio Estero), a dataset collected by ISTAT which registers the export activity of all Italian firms. Obviously, the necessity to link COE to MICRO.3 limits the sample of firms to those with 20 or more employees. Depending on the years, these firms represent between $75 \%$ and $80 \%$ of Italian exports.

Finally, the third source of microdata that we employ, is the Community Innovation Survey (CIS). We employ both the 2000 (CIS3) and 2004 (CIS4) waves. The CIS3 dataset is a cross-sectional survey of innovation activities performed by firms during the 1998-2000 period. The survey covers all the firms with 250 or more employees in 2000 and a sample of firms with less than 250 employees (with a minimum of 10 employees). In the end, there are 15512 firms in CIS3, of which 9034 are active in manufacturing sectors. The CIS4 survey covers the 2002-2004 period and employs the same methodology as the CIS3. It offers information about 21854 firms, of which 7586 are manufacturing firms. ${ }^{5}$ Notice that 5923 firms are present in both surveys (3194 for manufacturing) so that a total of 31443 of firms are covered in either of the two surveys (13575 for manufacturing). ${ }^{6}$ When linked to Micro.3, the sample is further reduced because some firms surveyed by CIS are below the 20 employee threshold of Micro.3. For the analysis on manufacturing sectors, we can use information about 5434 firms for CIS3 and 4206 for CIS4. 1845 are present in both surveys, so that a total of 7795 firms are covered.

\section{The macro evidence}

Let us start with an overview of the evidence on the relation between international competitiveness and innovation, as proxied by patents, at the country-sector level. A first snapshot is offered in Figure 1, displaying simple scatter plots for the relationship be-

\footnotetext{
${ }^{5}$ The lower proportion of manufacturing firms over the total in CIS4 with respect to CIS3 is mainly due to the fact the CIS4 covers also the construction sector, NACE Rev.1.1 45.

${ }^{6}$ The sectoral classification of firms refers to the two years of surveys, 2000 and 2004
} 


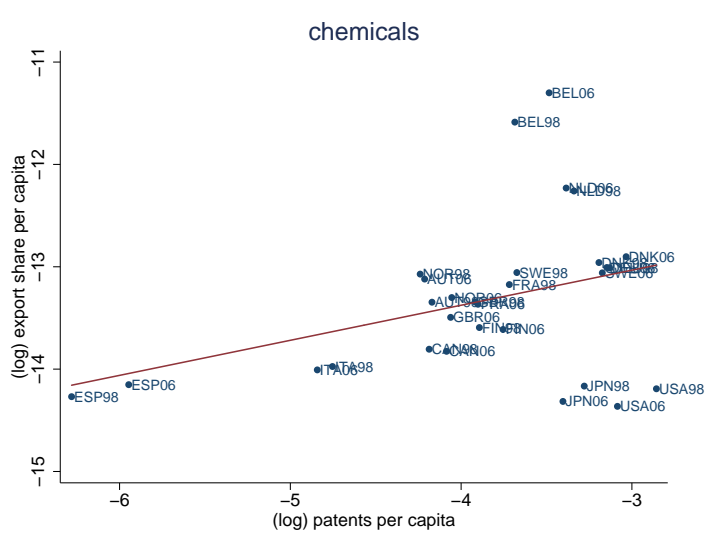

(a) $\beta=0.34(0.17) R^{2}=0.12$

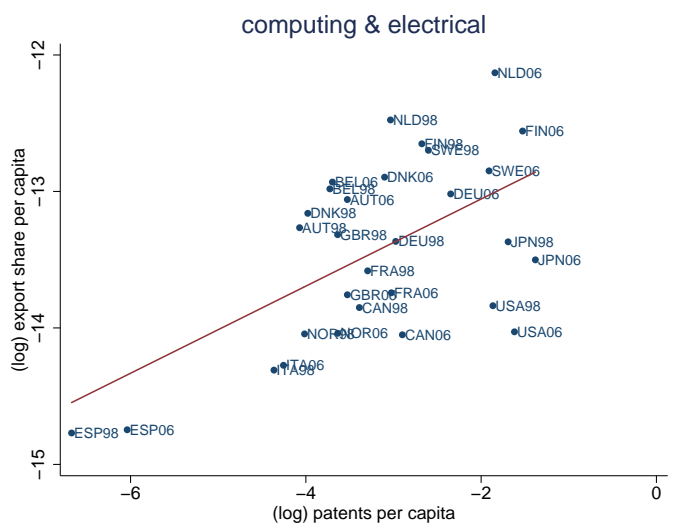

(c) $\beta=0.31(0.08) R^{2}=0.32$

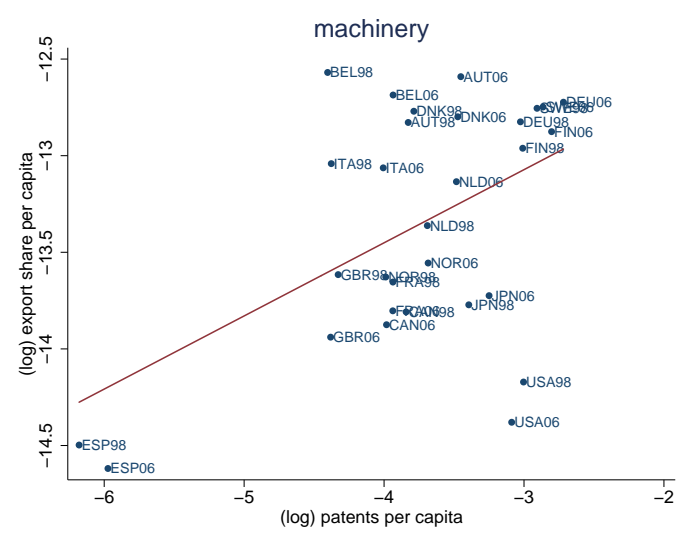

(b) $\beta=0.37(0.12) R^{2}=0.24$

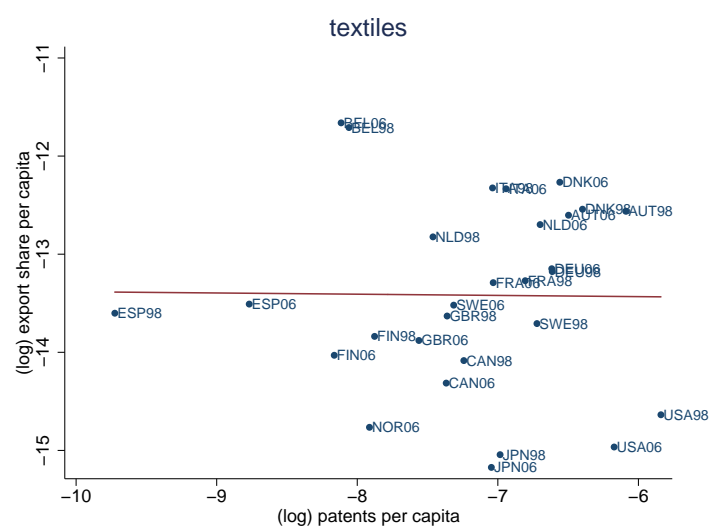

(d) $\beta=-0.01(0.22) R^{2}=0.00$

Figure 1: Patents and export shares, per capita terms, in 1998 and 2006.

tween (log) export shares per capita and (log) patents per capita, across countries and within four selected industries in 1998 and 2006.

A strong correlation between the two variables emerges sharply in many (even if not all) sectors: see in figure 1 three of the four sectors (chemicals, machinery, and computing), as shown both by the $R^{2}$ reported below each plot and by the $\beta$ 's (standard error in parenthesis).

The graphical analysis of the bivariate relationship between patents and international market shares leaves no doubt that technology strongly correlates with the pattern of international competitiveness among countries. This basic evidence about sectoral absolute advantages at the country level largely holds also at finer sectoral disaggregation.

Building upon the theoretical and empirical framework of Fagerberg (1988) and Dosi et al. (1990), let us study the simple relationship between an absolute measure of competitiveness (i.e. independent of the competitiveness of other sectors within the same country), and a set of costs and technology related variables. The dependent variable, our measure of (absolute) competitiveness, is represented by export market shares. The latter are calculated for a given country $i$ in industry $j\left(X M S_{i j}\right)$, by taking each country's exports in the industry (in current dollars) over the total industry's export from the 15 
countries of the OECD-STAN database.

Among the regressors, the cost variable is represented by the (current dollar) labour cost per employee $(W A G E)$. The industry labour productivity (PROD) is proxied by value added at constant prices divided by total employment (including the self-employed). ${ }^{7}$ The figure thus obtained is however an imperfect and possibly biased proxy for physical output if "absolute prices", even after the exchange rate corrections, are different across countries. In order to partly deal with such possible biases, sectoral productivities are converted, as often done, to a common currency by using PPP exchange rate of 2000 (i.e., the reference year of the national measure of real output in STAN database). ${ }^{8}$

Technology variables include a measure of investment intensity and patenting activity intensity, respectively $I N V$ and PATSH. INV is calculated as the ratio between industry expenditures on gross fixed capital formation and value added, both at current prices. PATSH is the share of national industry patents granted (both USPTO and EPO) over the sum of the industry's patents granted to the 15 countries.

The following regression is run for each of the 14 industries, and results are reported in Table 2:

$$
\begin{aligned}
X M S_{i j t}= & \beta_{1 j} W A G E_{i j t}+\beta_{2 j} P R O D_{i j t}+\beta_{3 j} I N V_{i j t} \\
& +\beta_{4 j} P A T S H_{i j t}+\beta_{5 j} P O P_{i t}+\epsilon_{i j t}
\end{aligned}
$$

where each variable is taken in $\log , i$ indexes countries, $j$ industries and $t$ time. POP stands for the total population and is included to control for the sheer size effect that influences the dependent variable.

The first noteworthy result is the strong significance of the patent variable across the vast majority of sectors. As expected, patented innovations appear to be important for competitiveness in sectors in which patents as a mean to appropriate returns from innovation play an important role (for the sectoral evidence see Levin et al., 1987 and the discussion in Dosi and Nelson, 2010). This is the case of the chemical sector and of the electrical and non-electrical machinery sectors, part of the "science-based" and the "specialised suppliers" categories according to Pavitt taxonomy (Pavitt, 1984). These three industries account for around $80 \%$ of total patents across countries in our sample. ${ }^{9}$ Patenting activity, on the contrary, is a poor proxy for product innovation in sectors where

\footnotetext{
${ }^{7}$ STAN database contains figures both on the number of employees and on the total employment. The first number is used to get the $W A G E$ variable, since labour costs refer only to employees. The second is used to get the $P R O D$ variable.

${ }^{8}$ It is worth noting that measures of PPP based on national GDP pose some problems on their own including the lack of adjustments for production prices, different VAT regimes - when used to revaluate industry output. At the very least we undertook the consistency check suggested by Sørensen (2001), i.e., using different base years for making the conversions. Results were largely unchanged.

${ }^{9}$ These three industries also report the highest patent intensity (number of patents over value added) as computed for USA industries in 2000 in OECD STAN dataset.
} 
Table 2: Industry regressions

\begin{tabular}{|c|c|c|c|c|c|c|}
\hline \multicolumn{7}{|c|}{ Dependent variable: export market share } \\
\hline & WAGE & PROD & INV & PATSH & Obs. & $R^{2}$ \\
\hline \multirow[t]{2}{*}{ All manufacturing } & $0.155^{b}$ & $0.347^{a}$ & $0.698^{a}$ & $0.270^{a}$ & \multirow[t]{2}{*}{3161} & \multirow[t]{2}{*}{0.68} \\
\hline & $(0.075)$ & $(0.046)$ & $(0.031)$ & $(0.015)$ & & \\
\hline \multirow[t]{2}{*}{ Food, beverages, tobacco } & 0.445 & $0.833^{b}$ & $0.924^{a}$ & $0.208^{b}$ & \multirow[t]{2}{*}{249} & \multirow[t]{2}{*}{0.36} \\
\hline & $(0.501)$ & $(0.362)$ & $(0.246)$ & $(0.088)$ & & \\
\hline \multirow[t]{2}{*}{ Textiles, wearing, leather } & -0.326 & $1.517^{a}$ & $1.288^{a}$ & 0.016 & \multirow[t]{2}{*}{227} & \multirow[t]{2}{*}{0.77} \\
\hline & $(0.316)$ & $(0.377)$ & $(0.120)$ & $(0.063)$ & & \\
\hline \multirow[t]{2}{*}{ Wood } & 0.284 & $2.217^{a}$ & $1.172^{a}$ & $0.426^{a}$ & \multirow[t]{2}{*}{221} & \multirow[t]{2}{*}{0.67} \\
\hline & $(0.283)$ & $(0.210)$ & $(0.121)$ & $(0.050)$ & & \\
\hline \multirow[t]{2}{*}{ Paper \& printing } & $-1.649^{a}$ & $1.415^{a}$ & -0.068 & $0.290^{a}$ & \multirow[t]{2}{*}{226} & \multirow[t]{2}{*}{0.78} \\
\hline & $(0.213)$ & $(0.164)$ & $(0.085)$ & $(0.025)$ & & \\
\hline \multirow[t]{2}{*}{ Coke \& petroleum } & 0.062 & -0.095 & $0.369^{a}$ & $0.384^{a}$ & \multirow[t]{2}{*}{200} & \multirow[t]{2}{*}{0.49} \\
\hline & $(0.206)$ & $(0.095)$ & $(0.104)$ & $(0.052)$ & & \\
\hline \multirow[t]{2}{*}{ Chemicals } & $1.594^{a}$ & 0.078 & 0.069 & $0.130^{b}$ & \multirow[t]{2}{*}{223} & \multirow[t]{2}{*}{0.78} \\
\hline & $(0.252)$ & $(0.171)$ & $(0.133)$ & $(0.060)$ & & \\
\hline \multirow[t]{2}{*}{ Rubber \& plastics } & -0.323 & 0.459 & $0.702^{a}$ & $0.238^{a}$ & \multirow[t]{2}{*}{223} & \multirow[t]{2}{*}{0.78} \\
\hline & $(0.323)$ & $(0.323)$ & $(0.136)$ & $(0.067)$ & & \\
\hline \multirow[t]{2}{*}{ Other non-metallic } & $-0.534^{b}$ & $0.469^{c}$ & $0.893^{a}$ & 0.021 & \multirow[t]{2}{*}{251} & \multirow[t]{2}{*}{0.79} \\
\hline & $(0.257)$ & $(0.244)$ & $(0.115)$ & $(0.048)$ & & \\
\hline \multirow[t]{2}{*}{ Basic metals } & $0.795^{a}$ & $0.834^{a}$ & $0.241^{b}$ & $0.163^{a}$ & \multirow[t]{2}{*}{190} & 0.76 \\
\hline & $(0.270)$ & $(0.134)$ & $(0.097)$ & $(0.048)$ & & \\
\hline Fabricated metal & -0.341 & -0.307 & $0.732^{a}$ & $0.314^{a}$ & 190 & 0.87 \\
\hline & $(0.224)$ & $(0.266)$ & $(0.097)$ & $(0.041)$ & & \\
\hline Machinery & -0.346 & 0.317 & $0.427^{a}$ & $0.341^{a}$ & 240 & 0.88 \\
\hline & $(0.212)$ & $(0.213)$ & $(0.072)$ & $(0.046)$ & & \\
\hline Computing \& electrical & -0.190 & 0.006 & $0.258^{a}$ & $0.424^{a}$ & 240 & 0.92 \\
\hline & $(0.179)$ & $(0.077)$ & $(0.073)$ & $(0.029)$ & & \\
\hline Transport equipment & $0.578^{a}$ & $1.326^{a}$ & $0.453^{a}$ & -0.046 & 251 & 0.91 \\
\hline & $(0.213)$ & $(0.122)$ & $(0.069)$ & $(0.041)$ & & \\
\hline Other manufacturing & -0.129 & $0.510^{b}$ & $0.875^{a}$ & 0.045 & 230 & 0.76 \\
\hline & $(0.273)$ & $(0.212)$ & $(0.122)$ & $(0.072)$ & & \\
\hline
\end{tabular}

Note. Pooled OLS estimation with standard errors in parentheses. Coefficient of POP omitted. Sector-year dummies (in the aggregate regression) and year dummies (in the sectoral regressions) included. ${ }^{a} p<0.01,{ }^{b} p<0.05,{ }^{c} p<0.10$.

they are indeed less relevant mechanisms of appropriation. This is the case, for example, of labour-intensive sectors such as textile or in industries that are intensive in the use of natural resources, such as non-metallic mineral products.

The $I N V$ variable, a proxy for capital-embodied, process innovation, is positive and significant in almost all sectors but two (paper and chemicals).

Interestingly, the coefficient for $W A G E$ is significant and negative only in two sectors (paper and non-metallic minerals sectors). Only there the lower costs of labor per employee appear to be relevant in sustaining country's exports. On the contrary, chemicals, basic metals and transport industries report a positive and significant coefficient on $W A G E$.

The results are broadly supportive of the evidence provided in Fagerberg (1988), Dosi 
et al. (1990), Amendola et al. (1993), and Amable and Verspagen (1995). In particular, they support the hypothesis that technology advantages dominate over cost-related factors in shaping international competitiveness. The question remains as to whether such predominance of technological versus cost factors still holds within sectors. Indeed, one might well find that at the country-sector level, differences in performances are driven by technological factors: a given country-sector can rip the benefits of the cumulated stock of knowledge, so that, at aggregate level, that country-sector gets a larger share of international trade. However, for firms within that country-sector pairs, the relation might not be isomorphic to the sectoral/aggregate ones. That is, even granted seemingly robust country- and sector- level correlations ${ }^{10}$, a crucial and still largely underinvestigated question concerns the microeconomics underlying such evidence.

Firms, irrespectively of the levels of disaggregation in terms of production activities, are highly heterogeneous on whatever measure chosen, both on the input and output sides, their efficiencies, degrees of innovativeness, market performances, even in presence of the same input prices (see, within an expanding literature, from Hildenbrand, 1981 and Nelson, 1981 to Bartelsman and Doms, 2000; Dosi and Grazzi, 2006; Dosi, 2007; Dosi and Nelson, 2010; Syverson, 2011). Hence, any "representative agent" hypothesis, in our view, is sufficiently discredited not to deserve serious discussion. But, then, what is actually the "micro" underlying whatever macro or "meso" evidence? In the following, we offer some explorations in this direction regarding export patterns.

\section{The micro evidence}

The available evidence supports also at least equally deep degrees of heterogeneity in the participation on the export markets (see the review in Bernard et al., 2012; Melitz and Trefler, 2012). Let us focus here on firm-level determinants of international competitiveness employing firm-level data matching balance-sheet accounts, innovation surveys, international patents, and export records.

In the following, we shall analyze the micro dynamics of Italian manufacturing exports in two steps: a first one, related to the probability of the firm of being an exporter (the so called "extensive margin") and a second one, related to the performance of exporting firms both in terms of shares (the so called "intensive margin") and in terms of growth rates. Notice that, fully acknowledging the intersectoral diversity in the data-generating processes, we shall, whenever allowed by the available data, stick to sector-specific estimates.

\footnotetext{
${ }^{10}$ Here and throughout we are very careful about any "causality" language. We do believe that causality in the evolutionary worlds we are trying to interpret goes both ways. Innovative success yields higher relative competitiveness - however measured - which in probability yields higher future capabilities of innovation. Hence, "endogeneity" is not amongst our primary concerns.
} 
Table 3: Percentage of firms exporting

\begin{tabular}{lcccc}
\hline & 1989 & 1994 & 2000 & 2006 \\
\hline All manufacturing & 64.06 & 72.58 & 75.87 & 77.76 \\
Food, beverages, tobacco & 51.99 & 66.86 & 74.33 & 77.27 \\
Textiles, wearing, leather & 61.54 & 65.78 & 72.91 & 76.92 \\
Wood & 46.95 & 59.40 & 66.88 & 66.55 \\
Paper \& printing & 51.12 & 66.74 & 69.28 & 73.11 \\
Coke \& petroleum & 36.62 & 47.62 & 41.67 & 54.08 \\
Chemicals & 78.19 & 87.47 & 91.99 & 92.84 \\
Rubber \& plastics & 73.68 & 86.88 & 86.74 & 89.82 \\
Other non-metallic & 54.34 & 61.31 & 64.76 & 63.95 \\
Basic metals & 67.86 & 80.66 & 82.56 & 84.62 \\
Fabricated metal & 54.35 & 64.02 & 63.52 & 65.41 \\
Machinery & 84.46 & 88.68 & 87.95 & 88.41 \\
Computing \& electrical & 62.85 & 73.32 & 74.67 & 80.90 \\
Transport equipment & 70.37 & 78.39 & 77.61 & 75.17 \\
Other manufacturing & 71.84 & 81.91 & 85.18 & 84.11 \\
\hline
\end{tabular}

Note. Our elaboration on Micro.3 and COE.

\subsection{Selection into export markets}

Let us start by addressing the factors affecting firm's drivers to enter foreign markets. Table 3 reports the percentage of exporting firms in four years, for the total manufacturing and by sectors. Over time, we observe an increasing share of the proportion of firms that export, around $64 \%$ and $78 \%$ in 1989 and 2006, respectively. Across sectors, one notices differences in the export propensity: the machinery and the chemical industries have around $90 \%$ exporting firms in 2006, while sectors like textiles, food, and transport equipment report significantly lower figures, around 76\%. Notice that these percentages refer to the export propensities of firms bigger than 20 employees. ${ }^{11}$ Still, one wants to understand why, among these firms, there are many that export and other that sell only on domestic markets: export status is not randomly assigned, but rather reminds of firms' specific "identity cards", that determine also their differential exporting behaviour. Export status is indeed quite stable: on the same dataset of Italian firms, Grazzi (2012) calculates a probability of around 0.9 that a firm exporting in year $t$ is still exporting in year $t+1$.

As we did in the sectoral analysis of Section 4, also here we shall take into account cost and technological variables as potential determinants of a firm's decision to export. We shall consider firm's labor productivity, $P R O D_{i t}$, defined as the ratio between value added (at constant prices) and employment; investment intensity, $I N V_{i t}$ as the ratio of acquired tangible assets to the firm's value added; average labour cost per employee, $W A G E_{i t}$; and finally, a dummy for patents, $P A T_{i t}$, taking value one if the firm's stock of patents is non empty.

\footnotetext{
${ }^{11}$ Export propensity for the whole population of Italian firms is much lower. For the aggregate manufacturing is around $20 \%$ (see, ICE-ISTAT, 2011, pag. 256).
} 
Investment intensity measures the degree to which a firm devotes resources to the acquisition of machineries and other kinds of industrial equipment which is likely to embody new technologies and thus new (cost-reducing) ways of producing goods. (It is a normalized measure (with respect to value added) since the amount of investments greatly depends on the size of the firm). The dynamics of firms' investment and its relation to performance are analyzed at length in Grazzi et al. (2013a) on the same set of data, finding a rather small, but positive and significant relation between so-called investment spikes and firms' productivity.

Some explanation is required for the patent dummy variable. As already mentioned, only a small fraction of Italian firms do patent. So, in our sample, in 1995 out of 20206 firms, only 579 (2.9\%) reported to have one or more patents and a mere 94 firms had two or more patents. $82 \%$ of all patenting firms are also exporters (compared to a $57 \%$ of exporters among non patenting firms). Given these patterns a dummy variable captures most of the information about patenting activity.

We estimate the following equation (all variables are expressed in log):

$$
\begin{aligned}
P\left(E_{X P} P_{i t}=1\right)=\Phi( & \alpha W A G E_{i t-1}+\beta P R O D_{i t-1} \\
& \left.+\gamma I N V_{i t-1}+\delta P A T t_{i t-1}+\phi E M P_{i t-1}+\epsilon_{i t}\right)
\end{aligned}
$$

where $E X P$ is a binary variable taking value one if the firm exports, and zero otherwise. $E M P_{i t-1}$ denotes the (log) number of employees and it is added as a control for possible size effects. The baseline econometric model describing the firm's decision to export is estimated through a probit model. A simple analytical strategy would of course take advantage of the panel dimension of the data, controlling for firm fixed effects. Unfortunately, within-group estimation fails to take into account the contribution of level variables, that is variables that do not vary or vary only in a negligible way through time within each firm. The patent dummy in equation (2) is exactly one of such variables. That is why we employ a pooled probit estimator. Results from the estimation of equation (2) are presented in Table 4.

Patents are significant and with a positive sign, in 10 out of 14 sectors. Among these, it is worth mentioning the machinery, the computing, and the transport sectors, in which the highest percentage of patenting firms is registered (respectively $12 \%, 7 \%$, and $7 \%$ in 2006). A bit more surprising is the result for the chemical sector, in which patents, as proxies for innovativeness, seem to play no significant role. ${ }^{12}$

A similar pattern is observed for investment intensity, which is not significantly differ-

\footnotetext{
${ }^{12}$ This is plausibly due to the very heterogeneity of the sector, which includes segments - like basic chemicals and plastics - where innovation-based advantages are not likely to influence export activities, and others - such as drugs and many organics chemicals - where it does. Numerosity problems do not allow meaningful further disaggregation. Granted that, see below on market shares and growth rates.
} 
Table 4: Selection into export markets

\begin{tabular}{|c|c|c|c|c|c|c|}
\hline \multicolumn{7}{|c|}{ Dependent variable: export dummy } \\
\hline & WAGE & PROD & INV & $\operatorname{PAT}(d)$ & Obs. & firms \\
\hline All manufacturing & $\begin{array}{c}0.034^{a} \\
(0.008)\end{array}$ & $\begin{array}{c}0.119^{a} \\
(0.005)\end{array}$ & $\begin{array}{c}0.011^{a} \\
(0.001)\end{array}$ & $\begin{array}{c}0.115^{a} \\
(0.007)\end{array}$ & 181524 & 39761 \\
\hline Food, beverages, tobacco & $\begin{array}{r}-0.007 \\
(0.030)\end{array}$ & $\begin{array}{r}0.132^{a} \\
(0.016)\end{array}$ & $\begin{array}{r}0.009^{b} \\
(0.004)\end{array}$ & $\begin{array}{c}0.144^{a} \\
(0.044)\end{array}$ & 14136 & 2941 \\
\hline Textiles, wearing, leather & $\begin{array}{r}-0.052^{a} \\
(0.020)\end{array}$ & $\begin{array}{c}0.253^{a} \\
(0.013)\end{array}$ & $\begin{array}{r}-0.017^{a} \\
(0.003)\end{array}$ & $\begin{array}{c}0.053 \\
(0.070)\end{array}$ & 32356 & 8030 \\
\hline Wood & $\begin{array}{c}0.044 \\
(0.062)\end{array}$ & $\begin{array}{c}0.204^{a} \\
(0.038)\end{array}$ & $\begin{array}{c}0.010 \\
(0.007)\end{array}$ & $\begin{array}{c}0.206^{a} \\
(0.061)\end{array}$ & 4854 & 1028 \\
\hline Paper \& printing & $\begin{array}{r}-0.274^{a} \\
(0.038)\end{array}$ & $\begin{array}{c}0.131^{a} \\
(0.023)\end{array}$ & $\begin{array}{r}0.023^{a} \\
(0.004)\end{array}$ & $\begin{array}{r}0.122^{c} \\
(0.066)\end{array}$ & 10635 & 2268 \\
\hline Coke \& petroleum & $\begin{array}{c}0.335^{b} \\
(0.149)\end{array}$ & $\begin{array}{r}-0.041 \\
(0.073)\end{array}$ & $\begin{array}{r}-0.014 \\
(0.015)\end{array}$ & $\begin{array}{r}-0.085 \\
(0.056)\end{array}$ & 915 & 158 \\
\hline Chemicals & $\begin{array}{c}0.038^{c} \\
(0.021)\end{array}$ & $\begin{array}{c}0.014 \\
(0.012)\end{array}$ & $\begin{array}{c}0.004 \\
(0.003)\end{array}$ & $\begin{array}{c}0.025 \\
(0.016)\end{array}$ & 9261 & 1714 \\
\hline Rubber \& plastics & $\begin{array}{c}0.107^{a} \\
(0.023)\end{array}$ & $\begin{array}{c}0.068^{a} \\
(0.013)\end{array}$ & $\begin{array}{c}0.009^{a} \\
(0.003)\end{array}$ & $\begin{array}{c}0.007 \\
(0.022)\end{array}$ & 9846 & 2074 \\
\hline Other non-metallic & $\begin{array}{c}0.283^{a} \\
(0.043)\end{array}$ & $\begin{array}{r}-0.106^{a} \\
(0.023)\end{array}$ & $\begin{array}{r}-0.008^{c} \\
(0.004)\end{array}$ & $\begin{array}{c}0.285^{a} \\
(0.030)\end{array}$ & 12685 & 2532 \\
\hline Basic metals & $\begin{array}{c}0.105^{a} \\
(0.039)\end{array}$ & $\begin{array}{c}0.063^{a} \\
(0.019)\end{array}$ & $\begin{array}{c}0.012^{a} \\
(0.004)\end{array}$ & $\begin{array}{c}0.163^{a} \\
(0.010)\end{array}$ & 7108 & 1236 \\
\hline Fabricated metal & $\begin{array}{c}0.067^{b} \\
(0.029)\end{array}$ & $\begin{array}{c}0.218^{a} \\
(0.019)\end{array}$ & $\begin{array}{c}0.034^{a} \\
(0.003)\end{array}$ & $\begin{array}{c}0.216^{a} \\
(0.024)\end{array}$ & 21541 & 5011 \\
\hline Machinery & $\begin{array}{c}0.054^{a} \\
(0.014)\end{array}$ & $\begin{array}{c}0.070^{a} \\
(0.008)\end{array}$ & $\begin{array}{c}0.009^{a} \\
(0.002)\end{array}$ & $\begin{array}{c}0.066^{a} \\
(0.007)\end{array}$ & 24312 & 5010 \\
\hline Computing \& electrical & $\begin{array}{c}0.095^{a} \\
(0.023)\end{array}$ & $\begin{array}{c}0.150^{a} \\
(0.015)\end{array}$ & $\begin{array}{c}0.041^{a} \\
(0.003)\end{array}$ & $\begin{array}{c}0.114^{a} \\
(0.014)\end{array}$ & 15294 & 3624 \\
\hline Transport equipment & $\begin{array}{c}0.169^{a} \\
(0.042)\end{array}$ & $\begin{array}{c}0.051^{a} \\
(0.020)\end{array}$ & $\begin{array}{c}0.012^{a} \\
(0.004)\end{array}$ & $\begin{array}{c}0.140^{a} \\
(0.015)\end{array}$ & 5725 & 1244 \\
\hline Other manufacturing & $\begin{array}{c}0.001 \\
(0.024)\end{array}$ & $\begin{array}{c}0.075^{a} \\
(0.014)\end{array}$ & $\begin{array}{c}0.001 \\
(0.003)\end{array}$ & $\begin{array}{c}0.094^{a} \\
(0.024)\end{array}$ & 12856 & 2891 \\
\hline
\end{tabular}

Note. Probit estimation. Marginal effects computed at means with robust standard errors clustered at the firm level in parentheses. (d) for discrete change of dummy variable from 0 to 1. Coefficient on EMP omitted. Sector-year dummies (in the aggregate regression) and year dummies (in the sectoral regressions) included. ${ }^{a} p<0.01,{ }^{b} p<0.05,{ }^{c} p<0.10$.

ent from zero in four sectors (and shows a negative effect in textiles), whereas productivity is not significant in just two sectors.

The $W A G E$ variable is often positive and significant, except in the paper and textiles sectors, where it is negative and significant, and in three other sectors (Food, wood and other manufacturing) where it is not significant. Hence, it would appear that not only cost of labour is not a general deterrent to export participation, but in many sectors firms with a higher cost per employee are more likely to export. Indeed wages are obviously an element of cost for the firm, but they also capture differential skills and, possibly, also that part of the "innovation rent" distributed to workers. This evidence is in agreement with much of the empirical work on the selection into export markets: exporting firms pay higher wages than non exporting firms (see Bernard and Jensen (1999) for evidence 
on manufacturing firms in USA and Serti et al. (2010) for evidence on Italy based on a previous version of the dataset used here).

The coefficient on the $(\log )$ number of employees, not reported in the table, is, as expected, positive and significant in all sectors: other things being equal larger firms are more likely to export.

Two clear messages emerge from the evidence presented above. First, the total labour compensation a firm pays does not appear to be a hindrance to export participation: to repeat, wage is positively related with the propensity to export in most sectors. It is of course hazardous to derive strong causal relationships from a single regression but the correlation is there and widespread.

Second, labour productivity dimension only capture a part of technological heterogeneity existing among firms. In fact, both the degree of investment intensity (a proxy for capital-embodied process innovation) and the propensity to patent (standing mostly for product innovation) are positively correlated with the probability to export in most sectors, even among firms with similar productivity levels.

Technology seems to be a crucial dimension that allows firms to take part or not to the export markets. In the next section, we will investigate to what extent, among exporting firms, technology and costs shape the dynamics of exports.

\section{$5.2 \quad$ Export market shares}

Let us now analyze the determinants of the changes in export market shares of Italian firms during the period 1989-2006. Once on the foreign markets, exporting firms compete with all firms from other countries. As a consequence, we relate the variation in relative exports of Italian firms to their relative characteristics and the variations thereof.

Our measure of competitiveness is export market share, $X M S_{i t}$, which refers to export market share of the firm $i$ (in a given sector) with respect to the sectoral OECD exports. It is calculated as the firm's exports (in dollar) over the total (dollar) exports from the 15 OECD countries for which data are available. As potential determinants of competitiveness, we consider again four variables. The relative wage, $R W A G E_{i t}$, is the wage rate ${ }^{13}$ (in current dollar) of the firm $i$ divided by the weighted average of wages (in current dollars) across countries. ${ }^{14}$

Similarly, the relative productivity and the relative investment intensity, $R P R O D_{i t}$ and $R I N V_{i t}$, are the productivity and the investment intensity of firm $i$ divided by the weighted average of productivity and investment intensity across countries. Finally, the patent dummy, $P A T_{i t}$, is defined as above.

\footnotetext{
${ }^{13}$ Defined as total labour costs per employee.

${ }^{14}$ The weights are the market shares of each country in 1998 and are kept fixed over the years as in Carlin et al. (2001) to avoid potential endogeneity problems. Choosing a different year or allowing the market shares to vary over time does not affect the results in any significant way.
} 
Table 5: Export market shares

\begin{tabular}{|c|c|c|c|c|c|c|}
\hline \multicolumn{7}{|c|}{ Dependent variable: export share } \\
\hline & RWAGE & RPROD & RINV & PAT & Obs. & firms \\
\hline All manufacturing & $\begin{array}{c}0.032 \\
(0.050)\end{array}$ & $\begin{array}{c}0.824^{a} \\
(0.026)\end{array}$ & $\begin{array}{c}0.082^{a} \\
(0.006)\end{array}$ & $\begin{array}{c}0.562^{a} \\
(0.040)\end{array}$ & 138241 & 31255 \\
\hline Food, beverages, tobacco & $\begin{array}{c}0.367^{a} \\
(0.137)\end{array}$ & $\begin{array}{r}0.852^{a} \\
(0.084)\end{array}$ & $\begin{array}{r}0.157^{a} \\
(0.026)\end{array}$ & $\begin{array}{r}1.073^{a} \\
(0.405)\end{array}$ & 9931 & 2310 \\
\hline Textiles, wearing, leather & $\begin{array}{r}-0.094 \\
(0.082)\end{array}$ & $\begin{array}{c}1.117^{a} \\
(0.057)\end{array}$ & $\begin{array}{r}-0.069^{a} \\
(0.014)\end{array}$ & $\begin{array}{c}0.799^{a} \\
(0.138)\end{array}$ & 23326 & 5778 \\
\hline Wood & $\begin{array}{c}0.317 \\
(0.296)\end{array}$ & $\begin{array}{c}0.246 \\
(0.208)\end{array}$ & $\begin{array}{c}0.017 \\
(0.042)\end{array}$ & $\begin{array}{r}1.762^{a} \\
(0.243)\end{array}$ & 3226 & 743 \\
\hline Paper \& printing & $\begin{array}{r}-1.188^{a} \\
(0.221)\end{array}$ & $\begin{array}{c}0.903^{a} \\
(0.140)\end{array}$ & $\begin{array}{c}0.223^{a} \\
(0.028)\end{array}$ & $\begin{array}{c}1.389^{a} \\
(0.350)\end{array}$ & 7249 & 1719 \\
\hline Chemicals & $\begin{array}{r}-0.179 \\
(0.139)\end{array}$ & $\begin{array}{c}0.713^{a} \\
(0.100)\end{array}$ & $\begin{array}{c}0.278^{a} \\
(0.029)\end{array}$ & $\begin{array}{r}0.277^{b} \\
(0.141)\end{array}$ & 8153 & 1578 \\
\hline Rubber \& plastics & $\begin{array}{c}0.487^{a} \\
(0.144)\end{array}$ & $\begin{array}{c}0.887^{a} \\
(0.107)\end{array}$ & $\begin{array}{c}0.059^{b} \\
(0.023)\end{array}$ & $\begin{array}{c}0.481^{a} \\
(0.113)\end{array}$ & 8492 & 1848 \\
\hline Other non-metallic & $\begin{array}{c}1.217^{a} \\
(0.150)\end{array}$ & $\begin{array}{r}-0.134 \\
(0.136)\end{array}$ & $\begin{array}{r}-0.041 \\
(0.026)\end{array}$ & $\begin{array}{c}0.861^{a} \\
(0.221)\end{array}$ & 8178 & 1755 \\
\hline Basic metals & $\begin{array}{r}-0.577^{a} \\
(0.140)\end{array}$ & $\begin{array}{c}0.989^{a} \\
(0.119)\end{array}$ & $\begin{array}{c}0.051^{c} \\
(0.029)\end{array}$ & $\begin{array}{c}0.210 \\
(0.334)\end{array}$ & 5743 & 1064 \\
\hline Fabricated metal & $\begin{array}{r}-0.242^{a} \\
(0.090)\end{array}$ & $\begin{array}{c}1.138^{a} \\
(0.095)\end{array}$ & $\begin{array}{c}0.104^{a} \\
(0.017)\end{array}$ & $\begin{array}{c}0.759^{a} \\
(0.122)\end{array}$ & 14647 & 3531 \\
\hline Machinery & $\begin{array}{c}0.105 \\
(0.069)\end{array}$ & $\begin{array}{c}0.858^{a} \\
(0.063)\end{array}$ & $\begin{array}{c}0.029^{b} \\
(0.012)\end{array}$ & $\begin{array}{c}0.479^{a} \\
(0.055)\end{array}$ & 21544 & 4531 \\
\hline Computing \& electrical & $\begin{array}{r}-0.026 \\
(0.131)\end{array}$ & $\begin{array}{c}0.236^{a} \\
(0.062)\end{array}$ & $\begin{array}{c}0.149^{a} \\
(0.021)\end{array}$ & $\begin{array}{c}0.722^{a} \\
(0.111)\end{array}$ & 12056 & 2796 \\
\hline Transport equipment & $\begin{array}{c}0.198 \\
(0.206)\end{array}$ & $\begin{array}{c}0.874^{a} \\
(0.156)\end{array}$ & $\begin{array}{c}0.131^{a} \\
(0.033)\end{array}$ & $\begin{array}{c}0.987^{a} \\
(0.171)\end{array}$ & 4680 & 1041 \\
\hline Other manufacturing & $\begin{array}{r}-0.685^{a} \\
(0.121)\end{array}$ & $\begin{array}{c}1.188^{a} \\
(0.104)\end{array}$ & $\begin{array}{c}0.067^{a} \\
(0.023)\end{array}$ & $\begin{array}{c}0.585^{a} \\
(0.156)\end{array}$ & 10562 & 2471 \\
\hline
\end{tabular}

Note. Pooled OLS estimation with robust standard errors clustered at the firm level in parentheses. Coefficient on EMP omitted. Sector and year dummies included in the first regression (All manufacturing). ${ }^{a} p<0.01,{ }^{b} p<0.05,{ }^{c} p<0.10$.

The baseline model describing the determinants of export market shares read as follows (all variables are in $\operatorname{logs}$ ):

$$
\begin{aligned}
X M S_{i t}= & \alpha R W A G E_{i t-1}+\beta R P R O D_{i t-1}+\gamma R I N V_{i t-1} \\
& +\delta P A T_{i t-1}+\phi E M P_{i t-1}+\epsilon_{i t}
\end{aligned}
$$

where $E M P_{i t-1}$ is added, again, to control for size effects. Equation (3) is estimated with pooled OLS for the reason explained above. Results are reported in Table $5^{15}$.

Patenting firms report, on average, higher export shares, with a "premium" that varies across sectors but is not significant only in basic metals. Relative investment intensity and relative labour productivity show a similar pattern across sectors. They are both

\footnotetext{
${ }^{15}$ Here, and in tables 6 and 7 , the coke \& petroleum sector is not taken into account due to the small number of exporting firms.
} 
significant in all industries but wood products and non-metallic minerals, where they are both not significant, and textile, where somewhat puzzlingly investment shows a negative sign. The coefficient on the number of employees, not reported in the table, is positive and significant in all sectors.

Relative labour compensation coefficients display a more ambiguous picture. In four industries (paper and printing, basic metals, metal products, other manufacturing), its negative and significant value shows that relative wages can be a factor reducing international competitiveness. However, it is either not significant or positive in the majority of sectors. As it was the case with the selection equation, we can conclude that also in this case relative wage captures, at least partly, different qualities of the workforce across firms, and some sharing by workers of any "competitiveness rent".

Notice that in order to estimate equation (3), the construction of relative measures of the variables on the right hand side allows to control for the specific trends in these variables that may affect the export performance of Italian firms. However, this leaves open the possibility that other general trends are not fully accounted for or that some change occurred in the way our variables determine firms' export market shares. In order to control for this possibility, and also for changes brought about by the Euro introduction, we estimate equation (3) on two separate samples, 1989-1995 (pre-Euro) and 2000-2006 (post-Euro). ${ }^{16}$ Results, not shown here, are much similar to those presented in Table 5, as far as the pre-Euro period is concerned, with the exception of the coefficient on wage in the first period, which is negative and significant for the aggregate manufacturing, and positive and significant in the machinery sector. In the period following the Euro introduction, the coefficient on wage becomes positive and significant in the aggregate regression and in textile sector (and not significant in three of the four sectors in which it was negative). These results hint at the possibility that cost competition became less important in some sectors after the Euro introduction. We also observe that in some sectors (food, transport, other manufacturing) there has been an increased importance of technological competition, as shown by the patent dummy coefficient: it was not significant in the first period and becomes positive and significant in the second period.

\subsection{Robustness}

As we have shown in Section 5.1, exporting firms tend to have specific characteristics that enable them to engage in competition with foreign firms on world markets. In this section, we adopt a standard Heckman model in order to check if the results about the determinants of export markets shares are driven by a selection bias.

In Table 6 we report the results obtained from the maximum likelihood estimation of a Heckman model in which the equation describing the selected sample is our market share

\footnotetext{
${ }^{16}$ Refer to Dosi et al. (2012) for an exercise on the same dataset that takes into account the Euro introduction.
} 
Table 6: Export market shares: Heckman selection model

\begin{tabular}{|c|c|c|c|c|c|c|}
\hline \multicolumn{7}{|c|}{ Dependent variable: export share } \\
\hline & RWAGE & RPROD & RINV & PAT & Obs. & firms \\
\hline All manufacturing & $\begin{array}{r}-0.025 \\
(0.045)\end{array}$ & $\begin{array}{c}0.679^{a} \\
(0.025)\end{array}$ & $\begin{array}{c}0.067^{a} \\
(0.006)\end{array}$ & $\begin{array}{c}0.517^{a} \\
(0.038)\end{array}$ & 181524 & 39761 \\
\hline Food, beverages, tobacco & $\begin{array}{c}0.537^{a} \\
(0.127)\end{array}$ & $\begin{array}{c}0.588^{a} \\
(0.079)\end{array}$ & $\begin{array}{c}0.140^{a} \\
(0.025)\end{array}$ & $\begin{array}{r}0.988^{b} \\
(0.417)\end{array}$ & 14136 & 2941 \\
\hline Textiles, wearing, leather & $\begin{array}{c}0.002 \\
(0.077)\end{array}$ & $\begin{array}{c}0.825^{a} \\
(0.055)\end{array}$ & $\begin{array}{r}-0.040^{a} \\
(0.013)\end{array}$ & $\begin{array}{c}0.780^{a} \\
(0.140)\end{array}$ & 32356 & 8030 \\
\hline Wood & $\begin{array}{c}0.484^{c} \\
(0.277)\end{array}$ & $\begin{array}{c}-0.004 \\
(0.199)\end{array}$ & $\begin{array}{c}0.003 \\
(0.040)\end{array}$ & $\begin{array}{c}1.710^{a} \\
(0.199)\end{array}$ & 4854 & 1028 \\
\hline Paper \& printing & $\begin{array}{r}-0.584^{a} \\
(0.205)\end{array}$ & $\begin{array}{c}0.720^{a} \\
(0.128)\end{array}$ & $\begin{array}{r}0.172^{a} \\
(0.026)\end{array}$ & $\begin{array}{c}1.295^{a} \\
(0.293)\end{array}$ & 10635 & 2268 \\
\hline Chemicals & $\begin{array}{r}-0.039 \\
(0.134)\end{array}$ & $\begin{array}{r}0.700^{a} \\
(0.093)\end{array}$ & $\begin{array}{r}0.269^{a} \\
(0.026)\end{array}$ & $\begin{array}{c}0.176 \\
(0.135)\end{array}$ & 9261 & 1714 \\
\hline Rubber \& plastics & $\begin{array}{r}0.475^{a} \\
(0.136)\end{array}$ & $\begin{array}{r}0.779^{a} \\
(0.099)\end{array}$ & $\begin{array}{r}0.053^{b} \\
(0.023)\end{array}$ & $\begin{array}{c}0.467^{a} \\
(0.099)\end{array}$ & 9846 & 2074 \\
\hline Other non-metallic & $\begin{array}{c}1.033^{a} \\
(0.138)\end{array}$ & $\begin{array}{c}0.004 \\
(0.124)\end{array}$ & $\begin{array}{r}-0.010 \\
(0.025)\end{array}$ & $\begin{array}{c}0.559^{a} \\
(0.202)\end{array}$ & 12685 & 2532 \\
\hline Basic metals & $\begin{array}{r}-0.508^{a} \\
(0.136)\end{array}$ & $\begin{array}{c}0.920^{a} \\
(0.113)\end{array}$ & $\begin{array}{c}0.052^{c} \\
(0.029)\end{array}$ & $\begin{array}{c}0.020 \\
(0.321)\end{array}$ & 7108 & 1236 \\
\hline Fabricated metal & $\begin{array}{r}-0.109 \\
(0.085)\end{array}$ & $\begin{array}{c}0.865^{a} \\
(0.088)\end{array}$ & $\begin{array}{c}0.069^{a} \\
(0.016)\end{array}$ & $\begin{array}{c}0.609^{a} \\
(0.115)\end{array}$ & 21541 & 5011 \\
\hline Machinery & $\begin{array}{c}0.067 \\
(0.065)\end{array}$ & $\begin{array}{c}0.735^{a} \\
(0.058)\end{array}$ & $\begin{array}{c}0.022^{c} \\
(0.011)\end{array}$ & $\begin{array}{c}0.352^{a} \\
(0.051)\end{array}$ & 24312 & 5010 \\
\hline Computing \& electrical & $\begin{array}{r}-0.083 \\
(0.121)\end{array}$ & $\begin{array}{c}0.297^{a} \\
(0.058)\end{array}$ & $\begin{array}{c}0.113^{a} \\
(0.020)\end{array}$ & $\begin{array}{c}0.547^{a} \\
(0.105)\end{array}$ & 15294 & 3624 \\
\hline Transport equipment & $\begin{array}{c}0.211 \\
(0.187)\end{array}$ & $\begin{array}{c}0.757^{a} \\
(0.142)\end{array}$ & $\begin{array}{c}0.121^{a} \\
(0.031)\end{array}$ & $\begin{array}{c}0.760^{a} \\
(0.163)\end{array}$ & 5725 & 1244 \\
\hline Other manufacturing & $\begin{array}{r}-0.510^{a} \\
(0.116)\end{array}$ & $\begin{array}{r}0.995^{a} \\
(0.099)\end{array}$ & $\begin{array}{c}0.063^{a} \\
(0.022)\end{array}$ & $\begin{array}{c}0.495^{a} \\
(0.141)\end{array}$ & 12856 & 2891 \\
\hline
\end{tabular}

Note. Maximum likelihood estimation of Heckman selection model with robust standard errors clustered at the firm level in parentheses. The excluded selection variable is the firm's export status at time $t-1$. Coefficient on $E M P$ omitted. Sector and year dummies included in the first regression (All manufacturing). ${ }^{a} p<0.01,{ }^{b} p<0.05,{ }^{c} p<0.10$.

equation (3) and the selection variable, excluded from the level equation, is the export status of the firm at time $t-1$. The number of firms and observations refer both to the censored and uncensored regression.

Based on the Wald test for the correlation of the error term of the selection and the level equation (not reported in the table), we reject in all sectors the hypothesis that the decision to export is independent from the amount of export themselves. As for the coefficients, most of the results obtained in section 5.2 through pooled OLS are qualitatively unchanged. The main difference concerns the wage variable in two sectors, fabricated metal and wood products: it is not significant in the first case, and positive and significant in the second. In all the other sectors, the pattern is the same observed in the previous section even if point estimates tend to be on average slightly smaller. 


\subsection{Market shares growth rates}

The analysis presented in the previous section dealt with the determinants of level of export shares, exploiting variations both between firms at each point in time and through time. In this section, we aim to investigate whether technology influences also the growth of export shares.

In order to do so, we take as new dependent variable the firms' growth rate of export market share. Among the regressors, we consider the same technology variables and controls as before, that is relative investment intensity, patent dummy and level of employment. The investment variable is kept in level because it already represents changes in the stock of capital equipment of a firm (see Carlin et al., 2001). On the contrary, here the patent dummy identifies whether the firms registered a new patent in any of the two years over which the growth rate of export market share is computed. The only relevant difference concerns the wage and the productivity variables. Labour productivity and average wage are the two "pieces" in which the unit labour cost of a firm can be decomposed. Up until now, we have avoided using the ratio of WAGE over PROD because it falls short of being an appropriate unit wage cost measure when taken in level. As it stands, it is more a measure of income distribution. Conversely, the growth rate of this ratio is an appropriate measure of changes in cost-competitiveness. Hence, in the following specification, we will employ changes in the ratio of $W A G E$ over PROD.

The equation that we estimate reads as follows:

$$
\Delta\left(X M S_{i t}\right)=\beta \Delta\left(R U L C_{i t}\right)+\gamma R I N V_{i t-1}+\delta P A T_{i t-1}+\phi E M P_{i t-1}+\epsilon_{i t}
$$

where $\Delta\left(X M S_{i t}\right)$ stands for the log difference of export market shares in two consecutive years and $\Delta\left(R U L C_{i t}\right)$ for the log difference of relative unit labour costs: in turn the latter is the log difference in wage rates minus the log difference in productivity between firm $i$ and the "the world" (which as above is made of our 15 OECD countries, weighted by the market shares of each country in 1998.)

Results from pooled OLS estimation of equation (4) are presented in Table 7.

Interestingly, the coefficient for the patent dummy has a positive and significant effect on the growth rates of market shares in four sectors, three of which being the most important ones in terms of total share of Italian exports. ${ }^{17}$ This result is somewhat surprising. As mentioned in the previous section, patenting is a very persistent variable, with very little dynamics so that a dummy variable captures a good deal of the information about it: being or not being a patenter is a sort of state variable, an integral part of the firm's "identity card". Considering together the results from level and growth rate equations suggest that patenting firms are able not only to gain, other things being equal,

\footnotetext{
${ }^{17}$ Chemical, machinery, and transport equipment together account for around two fifth of all Italian exports (Grazzi, 2012).
} 
Table 7: Export market shares: growth rates

\begin{tabular}{|c|c|c|c|c|c|}
\hline \multicolumn{6}{|c|}{ Dependent variable: export share's growth rate } \\
\hline & $\Delta \mathrm{RULC}$ & RINV & PAT & Obs. & firms \\
\hline All manufacturing & $\begin{array}{r}-0.145^{a} \\
(0.013)\end{array}$ & $\begin{array}{c}0.010^{a} \\
(0.002)\end{array}$ & $\begin{array}{c}0.046^{a} \\
(0.017)\end{array}$ & 126025 & 28683 \\
\hline Food, beverages, tobacco & $\begin{array}{r}-0.070^{b} \\
(0.036)\end{array}$ & $\begin{array}{c}0.016^{c} \\
(0.008)\end{array}$ & $\begin{array}{c}0.093 \\
(0.143)\end{array}$ & 8805 & 2086 \\
\hline Textiles, wearing, leather & $\begin{array}{r}-0.078^{a} \\
(0.022)\end{array}$ & $\begin{array}{c}0.004 \\
(0.005)\end{array}$ & $\begin{array}{c}0.074 \\
(0.090)\end{array}$ & 21255 & 5251 \\
\hline Wood & $\begin{array}{c}0.045 \\
(0.074)\end{array}$ & $\begin{array}{c}0.016 \\
(0.015)\end{array}$ & $\begin{array}{c}0.138 \\
(0.167)\end{array}$ & 2840 & 646 \\
\hline Paper \& printing & $\begin{array}{r}-0.016 \\
(0.079)\end{array}$ & $\begin{array}{c}0.038^{a} \\
(0.010)\end{array}$ & $\begin{array}{c}0.186 \\
(0.289)\end{array}$ & 6324 & 1508 \\
\hline Chemicals & $\begin{array}{r}-0.127^{a} \\
(0.039)\end{array}$ & $\begin{array}{c}0.005 \\
(0.009)\end{array}$ & $\begin{array}{c}0.063^{c} \\
(0.037)\end{array}$ & 7579 & 1509 \\
\hline Rubber \& plastics & $\begin{array}{c}0.010 \\
(0.047)\end{array}$ & $\begin{array}{c}0.022^{b} \\
(0.009)\end{array}$ & $\begin{array}{c}0.001 \\
(0.040)\end{array}$ & 7917 & 1736 \\
\hline Other non-metallic & $\begin{array}{r}-0.031 \\
(0.045)\end{array}$ & $\begin{array}{c}0.015 \\
(0.010)\end{array}$ & $\begin{array}{c}0.135^{b} \\
(0.056)\end{array}$ & 7308 & 1579 \\
\hline Basic metals & $\begin{array}{c}0.009 \\
(0.060)\end{array}$ & $\begin{array}{c}0.006 \\
(0.012)\end{array}$ & $\begin{array}{c}0.197 \\
(0.171)\end{array}$ & 5266 & 990 \\
\hline Fabricated metal & $\begin{array}{c}0.047 \\
(0.034)\end{array}$ & $\begin{array}{c}0.010 \\
(0.007)\end{array}$ & $\begin{array}{c}0.012 \\
(0.054)\end{array}$ & 13040 & 3126 \\
\hline Machinery & $\begin{array}{c}0.022 \\
(0.028)\end{array}$ & $\begin{array}{c}0.020^{a} \\
(0.005)\end{array}$ & $\begin{array}{c}0.049^{c} \\
(0.028)\end{array}$ & 20300 & 4340 \\
\hline Computing \& electrical & $\begin{array}{c}0.131^{a} \\
(0.043)\end{array}$ & $\begin{array}{r}-0.000 \\
(0.007)\end{array}$ & $\begin{array}{c}0.052 \\
(0.057)\end{array}$ & 11155 & 2603 \\
\hline Transport equipment & $\begin{array}{c}0.042 \\
(0.080)\end{array}$ & $\begin{array}{c}0.013 \\
(0.013)\end{array}$ & $\begin{array}{r}0.253^{a} \\
(0.095)\end{array}$ & 4204 & 946 \\
\hline Other manufacturing & $\begin{array}{r}-0.034 \\
(0.030)\end{array}$ & $\begin{array}{c}0.017^{b} \\
(0.008)\end{array}$ & $\begin{array}{r}-0.098 \\
(0.086)\end{array}$ & 9654 & 2287 \\
\hline
\end{tabular}

Note. Pooled OLS estimation with robust standard errors clustered at the firm level in parentheses. Coefficient on $E M P$ omitted. Sector and year dummies included in the first regression (All manufacturing). ${ }^{a} p<0.01,{ }^{b} p<0.05,{ }^{c} p<0.10$.

higher market shares on foreign markets, but also to display, in some industries, higher growth rates.

Investments appear to be less relevant as compared to the equation in levels: they turn out to be significantly different from zero in five sectors. Notably, in only one of these (machinery) patents are significant, too. Such an evidence hints at the different importance in different sectors of product innovation (mostly proxied by patents) and capital-embodied process innovation (captured by investment intensity) as drivers of the firms' growth rate of export shares.

Coefficients of $\triangle R U L C_{i t}$ take the negative sign in only three sectors: food, textile, and chemicals, the former two being largely traditional, where a cost-based competition may be expected to be more relevant. It is even positive in the electrical machinery sector, while in all other sectors is not significantly different from zero. 


\section{Product versus process innovation}

So far we have tried to relate innovative activity to export employing firm level data from balance sheets and patents. We now resort to the Italian section of the Community Innovation Survey (CIS) for complementary measures of product and process innovation. In the following we will use data from the 2000 (CIS3) and 2004 (CIS4) surveys. The CIS surveys report answers provided by the firms to a questionnaire concerning various aspects of their innovative activities. They have been already employed to investigate the relation between innovation and firm performance, both in Italy (see among the others Vivarelli et al., 1996) and in other European countries (see Belderbos et al., 2004; Harris and Li, 2009; Van Beveren and Vandenbussche, 2010, for the Netherlands, UK, and Belgium respectively). In particular, we will use three different variables. The first one indicates whether the firm introduced new products during the reference time period (1998-2000 for CIS3 and 2002-2004 for CIS4), the second one indicates whether the firm introduced new processes over the same periods while the third one selects, among the firms that introduced a new product, those which introduced a product not only new for the firm but also new for their reference market. ${ }^{18}$

Table 8 reports the differences between innovators in terms of the propensity to export and export shares among exporting firms. Notice that as the number of observations is greatly reduced with respect to previous specifications, we run a pooled regression for all manufacturing sectors, controlling for industry fixed effect by means of dummy variables. Columns (1) and (3) report the innovation premia estimated from the following regression:

$$
X_{i}=\alpha I N N_{i}+\text { sector }_{i}+\epsilon_{i}
$$

where $I N N$ is one of the two measures of innovation, product or process and $X$ is either an export dummy or the (log) of export share. Columns (2) and (4) estimate the same equation also including an additional control for size, measured in terms of employment. Note that we run two separate regression on the two CIS wave (CIS3 and CIS4). There is indeed a very small overlapping between the firms that are surveyed in the two samples, since only firms above 100 employees appear in both waves, and they are a small percentage of the total (this also implies that it is not possible to apply panel estimation techniques).

Among innovators, there is a higher percentage of exporting firms, ranging between $13.2 \%$ and $14.8 \%$ in the case of product innovation, and between $10 \%$ and $11.7 \%$ in the case of process innovation. The premia are lower when the size of the firm is taken into

\footnotetext{
${ }^{18}$ The questionnaires sent to firms are available online at http://epp.eurostat.ec.europa.eu/ portal/page/portal/microdata/cis. The variables that we use in this work are related to question $1.1,1.4$, and 2.1 in CIS3 questionnaire and to question 2.1, 2.3, and 3.1 in CIS4 questionnaire.
} 
Table 8: Innovation premia

\begin{tabular}{lcccc}
\hline & CIS3 & \multicolumn{2}{c}{ CIS4 } \\
& $(1)$ & $(2)$ & $(3)$ & $(4)$ \\
\hline Panel A: Product innovation premia \\
Exporting FIRMS & 14.8 & 10.9 & 13.2 & 9.4 \\
ExPORT SHARES & 116.2 & 54.7 & 115.1 & 51.3 \\
Panel B: Process innovation premia & \\
ExporTING FIRMS & 10.0 & 6.4 & 11.7 & 8.3 \\
ExPORT SHARES & 80.2 & 22.9 & 84.2 & 25.0 \\
\hline
\end{tabular}

Note. The table reports innovation premia, in percentage, estimated from equation 5. Columns (2) and (4) control for total employment. All differences are significant at the $1 \%$ level.

account, but they are still significant, both from a statistical and from an economic point of view. Among exporting firms, the ones that introduced a product or a process innovation report export shares that, after controlling for firm employment, are much higher than those of non innovating firms: the difference ranges between $51.3 \%$ and $54.7 \%$ for product, and between $22.9 \%$ and $25 \%$ for process innovation. A robust feature emerging from the two waves of CIS is that, on average, product innovation premia are higher than process innovation premia.

Next, let us proceed to verify the robustness of the findings of the previous section on the impact of innovation on propensity to export and on market share. For sake of comparability of results, we keep the regression models as close as possible to those just presented, only refining the measures for product and process innovation. In particular, we use three dummy variables denoting respectively firms that introduced only a product innovation (INPDT), firms that introduced only a process innovation (INPCS), and firms that introduced both $(B O T H)$. These variables are mutually exclusive so that the high correlation between product and process innovation does not show up in the regressions. ${ }^{19}$ In addition, we use a dummy variable $(N E W M K T)$ denoting firms that introduced a product that was new also for their reference market. ${ }^{20}$

We start to investigate the impact of innovation on the propensity to export in a setting similar to that of equation (2) and we estimate two probit models

\footnotetext{
${ }^{19}$ For example, in CIS3, of 2141 firms reporting the introduction of a new product, and 2038 firms the introduction of a new process, 1463 firms introduced both a product and a process innovation: that is, around $70 \%$ of product innovators are also process innovators. Figures are similar for CIS4.

${ }^{20}$ Among firms introducing a product innovation, $82 \%$ and $69 \%$ are the percentage of firms that considered the product new also for the market, in CIS3 and CIS4 respectively.
} 
Table 9: Selection, CIS3 and CIS4

\begin{tabular}{lcccc}
\hline & \multicolumn{2}{c}{ CIS3 } & \multicolumn{2}{c}{ CIS4 } \\
& $(1)$ & $(2)$ & $(3)$ & $(4)$ \\
\hline WAGE & -0.046 & -0.029 & -0.005 & 0.028 \\
& $(0.028)$ & $(0.020)$ & $(0.031)$ & $(0.026)$ \\
PROD & $0.142^{a}$ & $0.073^{a}$ & $0.120^{a}$ & 0.011 \\
& $(0.021)$ & $(0.018)$ & $(0.019)$ & $(0.013)$ \\
INPDT & $0.092^{a}$ & & $0.092^{a}$ & \\
& $(0.011)$ & & $(0.011)$ & \\
INPCS & $0.025^{c}$ & & $0.050^{a}$ & \\
& $(0.014)$ & & $(0.012)$ & \\
BOTH & $0.077^{a}$ & & $0.093^{a}$ & \\
& $(0.011)$ & & $(0.011)$ & \\
NEWMKT & & 0.019 & & $0.025^{b}$ \\
& & $(0.013)$ & & $(0.012)$ \\
\hline$N$ & 4521 & 1852 & 3609 & 1185 \\
pseudo $R^{2}$ & 0.183 & 0.185 & 0.172 & 0.159 \\
\hline Note. Probit & & &
\end{tabular}

Note. Probit estimation of equation (6) in colums (1) and (3) and of equation (7) in columns (2) and (4). Marginal effects calculated at the mean for continuous variables; discrete change from 0 to 1 for dummy variables. Robust standard error in parenthesis. Coefficient on EMP omitted. Sector dummies included. ${ }^{a}$ $p<0.01,{ }^{b} p<0.05,{ }^{c} p<0.10$

$$
\begin{gathered}
E X P i=\alpha W A G E_{i}+\beta P R O D_{i}+\gamma I N P C S_{i}+\delta I N P D T_{i} \\
+\zeta B O T H_{i}+\phi E M P_{i}+\epsilon_{i} \\
E X P i=\alpha W A G E_{i}+\beta P R O D_{i}+\gamma N E W M K T_{i}+\epsilon_{i}
\end{gathered}
$$

where the dummy variables INPCS, INPDT, and BOTH replace $I N V$ and PAT, respectively. Equation (7) is estimated only on the subsample of firms that introduced a product innovation. Variables are not indexed by $t$ as we run two different regression on the two waves of the CIS. In order to minimize simultaneity biases, the regressors and the dependent variable are measured at different time periods. Regressors refer respectively to 1998-2000 and 2002-2004 for CIS3 and CIS4 (they are averages in the case of continuous variables), while the dummy for export status refers to 2001 and 2005. Results of the estimation of equation (6) and (7) are reported in Table 9.

We then investigate the impact of innovation on firms' market shares in a setting that is similar to that of equation (3), and we now exploit CIS variables to estimate the following model: 
Table 10: Export market shares, CIS3 and CIS4

\begin{tabular}{lcccc}
\hline & \multicolumn{2}{c}{ CIS3 } & \multicolumn{2}{c}{ CIS4 } \\
& $(1)$ & $(2)$ & $(3)$ & $(4)$ \\
\hline WAGE & $-0.638^{b}$ & $-0.627^{c}$ & 0.318 & $0.698^{c}$ \\
& $(0.266)$ & $(0.369)$ & $(0.256)$ & $(0.373)$ \\
PROD & $1.303^{a}$ & $1.171^{a}$ & $1.037^{a}$ & $0.778^{a}$ \\
& $(0.147)$ & $(0.199)$ & $(0.136)$ & $(0.202)$ \\
INPDT & $0.457^{a}$ & & $0.271^{a}$ & \\
& $(0.096)$ & & $(0.126)$ & \\
INPCS & -0.019 & & 0.075 & \\
& $(0.116)$ & & $(0.111)$ & \\
BOTH & $0.291^{a}$ & & $0.342^{a}$ & \\
& $(0.083)$ & & $(0.095)$ & \\
NEWMKT & & 0.047 & & -0.015 \\
& & $(0.118)$ & & $(0.127)$ \\
\hline$N$ & 3699 & 1680 & 3014 & 1110 \\
$R^{2}$ & 0.425 & 0.478 & 0.407 & 0.510 \\
\hline
\end{tabular}

Note. OLS estimation of equation (8) in columns (1) and (3) and of equation (9) in columns (2) and (4). Robust standard error in parenthesis. Coefficient on EMP omitted. Sector dummies included. ${ }^{a} p<0.01,{ }^{b} p<0.05,{ }^{c} p<0.10$

$$
\begin{aligned}
X M S_{i}= & \alpha W A G E_{i}+\beta P R O D_{i}+\gamma I N P C S_{i}+\delta I N P D T_{i} \\
& +\zeta B O T H_{i}+\phi E M P_{i}+\epsilon_{i}
\end{aligned}
$$

and we also test:

$$
X M S_{i}=\alpha W A G E_{i}+\beta P R O D_{i}+\gamma N E W M K T_{i}+\epsilon_{i}
$$

where export market shares, wage rates and productivities are calculated in 2000 and 2004 for CIS3 and CIS4, respectively. Results from OLS estimation are reported in Table 10 .

Results from Tables 9 are in agreement with the ones obtained using the full sample of Micro.3 and COE and pooling all manufacturing sectors together. Productivity levels are positively correlated with the propensity to export (except in column (4)), and the same positive effect holds for the three innovation variables. We find that the simultaneous introduction of a product and process innovation has an impact on firms' export propensity, in line with the results of Becker and Egger (2013). However, differently from them, we find that also process innovation in isolation has an effect, even if the effect is lower than the one obtained from product innovation alone, in agreement with the findings 
of Caldera (2010). The relevant difference with respect to the regression using Micro.3 and $\mathrm{COE}$ is in the wage coefficient, which is here not significant. The introduction of a product which is new also for the market shows some effect only in the CIS4 regression.

Results from Tables 10 show a negative and significant coefficient on wage for CIS3, and positive or non significant for CIS4: another hint that cost competition might have become less important over time (see section 5.2). Introducing a new product or introducing both a new product and a new process does impact on export market shares; on the other hand, we do not find any effect for process innovation in isolation or for a product which is new also for the market.

\section{Conclusions}

The paper contributes to the analysis of the the determinants of international competitiveness offering both the macro and the micro evidence about the relevance of cost and technological competition, vindicating also at a micro level the broad conjecture stemming from technology gap theories of international trade according to which the primary drivers of international competitiveness are lags and leads in sector-specific process and product innovation compared to other countries, rather than inter-sectoral patterns of allocation of resources within each country.

As one argues at greater length in Cimoli et al. (2009b) and in particular in Reinert (2009) and Cimoli et al. (2009a), in most of trade theories - from Ricardo to modern endowment-based theories of specialization, but also to contemporary "structural" micro models -, the General Equilibrium inspiration leads to a theorizing ultimately based on some opportunity-cost drivers of specialization. This is the spirit of Ricardo's argument on the notional opening up to trade by a "England" and a "Portugal" producing "wine" and "cloth". However, somewhat dramatizing, one asks in Reinert (2009) and Cimoli et al. (2009a) what happens if one opens up trade between a "Stone Age economy" and an ICT-based one? Most likely, if there will be bilateral trade at all, the "Stone intensive" economy will be more likely to export "stone intensive" products. However, will it? Maybe, the more advanced ICT economy will produce almost anything worth trading irrespective of the stone- or ICT- intensities of the products. What matters might be ultimately technological capabilities and not relative prices (and even less so shadow prices). Technology gap theories of trade hint at this broad property.

Consider the foregoing analysis as a still preliminary exploration of the microeconomics of such dynamics.

Results of the empirical exercise in the first part show that technological capabilities are indeed crucial factors in explaining trade patterns between countries. Labour costs, on the contrary, have an ambiguous effect on export market shares: they have a negative sign in just two sectors, while in most cases they are either positive or not significant. 
The analysis at the micro level provides the first large scale study on export behaviour of firms which accounts also for the role of innovation. The micro evidence has been decomposed in two different processes: the selection of firms into export markets and the dynamics of market shares with respect to a subset of OECD countries. In both cases, technology has been found to have a relevant role. How much a firm invests and if a firm patents appears to be correlated both to the probability of being an exporter and to the capacity to acquire and sustain market shares. On the other hand, the evidence about costs is mixed. Simple wage expenditure shows a positive correlation with the probability of being an exporter, while relative unit labour costs, a more appropriate measure of cost competitiveness, seems to be relevant only in some sectors.

We conclude with a set of results about the role of product and process innovation using CIS data, as it is usually done in the literature addressing the role of innovation in firms export behaviour. Results from CIS survey confirm the previous findings. In particular, they show that product innovation is a more relevant dimension than process innovation in determining firms export success.

This evidence, of course, corroborates the notion that at macro levels, technological absolute advantages do matter, as predicted by the interpretations of trade flows in Posner (1961), Hirsch (1965), Fagerberg (1988), and Dosi et al. (1990) among few heterodox others. At the micro level, the evidence speaks in favor of models of trade based on "quality sorting" more than "efficiency sorting", along the conclusions drawn at the product level in Manova and Zhang (2012), but the implications might go well beyond, urging the abandonment of interpretations of trade patterns which rely too quickly upon incentive-driven allocations of fungible resources as compared to activity-spcific, persistently different, asymmetric firm-level technological capabilities. 


\section{References}

Amable, B. And B. Verspagen (1995): "The role of technology in market shares dynamics," Applied Economics, 27, 197-204.

Amendola, G., G. Dosi, And E. Papagni (1993): "The dynamics of international competitiveness," Review of World Economics (Weltwirtschaftliches Archiv), 129, 451471.

Bartelsman, E. J. And M. Doms (2000): "Understanding Productivity: Lessons from Longitudinal Microdata," Journal of Economic Literature, 38, 569-594.

BASILE, R. (2001): "Export behavior of Italian manufacturing firms over the nineties: The role of innovation," Research Policy, 30, 1185-1201.

Becker, S. AND P. EgGer (2013): "Endogenous product versus process innovation and a firms propensity to export," Empirical Economics, 44, 329-354.

Belderbos, R., M. Carree, and B. Lokshin (2004): "Cooperative R\&D and firm performance," Research Policy, 33, 1477-1492.

Berman, N., P. Martin, And T. Mayer (2012): "How do Different Exporters React to Exchange Rate Changes?" The Quarterly Journal of Economics, 127, 437-492.

Bernard, A. B. And J. Jensen (1999): "Exceptional exporter performance: cause, effect, or both?" Journal of International Economics, 47, 1-25.

Bernard, A. B. And J. B. Jensen (2004): "Why Some Firms Export," The Review of Economics and Statistics, 86, 561-569.

Bernard, A. B., J. B. Jensen, S. J. Redding, and P. K. Schott (2012): "The Empirics of Firm Heterogeneity and International Trade," Annual Review of Economics, 4, 283-313.

CAldera, A. (2010): "Innovation and exporting: evidence from Spanish manufacturing firms," Review of World Economics (Weltwirtschaftliches Archiv), 146, 657-689.

Carlin, W., A. Glyn, And J. Van Reenen (2001): "Export Market Performance of OECD Countries: An Empirical Examination of the Role of Cost Competitiveness," Economic Journal, 111, 128-62.

Castellacci, F. (2008): "Innovation and the competitiveness of industries: Comparing the mainstream and the evolutionary approaches," Technological Forecasting and Social Change, 75, 984-1006. 
Castellani, D. And A. Zanfei (2007): "Internationalisation, Innovation and Productivity: How Do Firms Differ in Italy?" The World Economy, 30, 156-176.

Cefis, E. And L. Orsenigo (2001): "The persistence of innovative activities:: A crosscountries and cross-sectors comparative analysis," Research Policy, 30, 1139-1158.

Cimoli, M. (1988): "Technological gaps and institutional asymmetries in a North-South model with a continuum of goods," Metroeconomica, 39, 245-274.

Cimoli, M., G. Dosi, And J. E. Stiglitz (2009a): "The future of industrial policies in the new millennium: Toward a knowledge-centered development agenda," in Industrial Policy and Development: The Political Economy of Capabilities Accumulation, ed. by M. Cimoli, G. Dosi, and J. E. Stiglitz, Oxford University Press.

Cimoli, M., G. Dosi, And J. E. Stiglitz, eds. (2009b): Industrial Policy and Development: The Political Economy of Capabilities Accumulation, Oxford University Press.

Dosi, G. (2007): "Statistical Regularities in the Evolution of Industries. A Guide through some Evidence and Challenges for the Theory," in Perspectives on Innovation, ed. by F. Malerba and S. Brusoni, Cambridge University Press.

Dosi, G. AND M. Grazzi (2006): "Technologies as problem-solving procedures and technologies as input-output relations: some perspectives on the theory of production," Industrial and Corporate Change, 15, 173-202.

Dosi, G., M. Grazzi, C. Tomasi, And A. Zeli (2012): "Turbulence underneath the big calm? The micro-evidence behind Italian productivity dynamics," Small Business Economics, 39, 1043-1067.

Dosi, G. And R. R. Nelson (2010): "Technological change and industrial dynamics as evolutionary processes," in Handbook of the Economics of Innovation, ed. by B. H. Hall and N. Rosenberg, Elsevier: Amsterdam, chap. 4.

Dosi, G., K. Pavitt, And L. Soete (1990): The Economics of Technical Change and International Trade, New York University Press: New York.

FAGerberG, J. (1988): "International competitiveness," The Economic Journal, 98, $355-374$.

Freeman, C. (1963): "The Plastics Industry: a Comparative Study of Research and Innovation," National Institute Economic Review, 26, 22-62.

Grazzi, M. (2012): "Export and Firm Performance: Evidence on Productivity and Profitability of Italian Companies," Journal of Industry, Competition and Trade, 12, 413-444. 
Grazzi, M., N. Jacoby, And T. Treibich (2013a): "Dynamics of Investment and Firm Performance: Comparative evidence from manufacturing industries," LEM Papers Series 2013/06, Laboratory of Economics and Management (LEM), Sant'Anna School of Advanced Studies, Pisa, Italy.

Grazzi, M., R. Sanzo, A. Secchi, And A. Zeli (2013b): "The building process of a new integrated system of business micro-data 1989-2004," Journal of Economic and Social Measurement, 38, 291-324.

Greenaway, D. And R. Kneller (2007): "Firm heterogeneity, exporting and foreign direct investment," Economic Journal, 117, F134-F161.

HARRIS, R. AND Q. C. Li (2009): "Exporting, R\&D, and absorptive capacity in UK establishments," Oxford economic papers, 61, 74-103.

Hildenbrand, W. (1981): "Short-Run Production Functions Based on Microdata," Econometrica, 49, 1095-1125.

Hirsch, S. (1965): "The United States electronics industry in international trade," $N a$ tional Institute Economic Review, 34, 92-97.

Hufbauer, G. C. (1970): "The Impact of National Characteristics \& Technology on the Commodity Composition of Trade in Manufactured Goods," in The Technology Factor in International Trade, ed. by R. Vernon, Columbia University Press: New York, 143232.

ICE-ISTAT (2011): Commercio estero e attività internazionali delle imprese. Rapporto Annuale 2010, vol. 1, Istituto Commercio Estero and Istituto Nazionele di Statistica.

KALDOR, N. (1978): "The effect of devaluations on trade in manufactures," in in Further essays on applied economics, Duckworth: London, 99-118.

Laursen, K. And V. Meliciani (2010): "The role of ICT knowledge flows for international market share dynamics," Research Policy, 39, 687-697.

Levin, R. C., A. K. Klevorick, R. R. Nelson, S. G. Winter, R. Gilbert, AND Z. GRILICHES (1987): "Appropriating the Returns from Industrial Research and Development," Brookings Papers on Economic Activity, 1987, 783-831.

Malerba, F. And L. Orsenigo (1999): "Technological entry, exit and survival: an empirical analysis of patent data," Research Policy, 28, 643-660.

Manova, K. And Z. Zhang (2012): "Export Prices Across Firms and Destinations," The Quarterly Journal of Economics, 127, 379-436. 
Mayer, T., M. J. Melitz, and G. I. Ottaviano (2011): "Market Size, Competition, and the Product Mix of Exporters," NBER Working Papers 16959, National Bureau of Economic Research, Inc.

Melitz, M. J. (2003): "The Impact of Trade on Intra-Industry Reallocations and Aggregate Industry Productivity," Econometrica, 71, 1695-1725.

Melitz, M. J. And D. Trefler (2012): "Gains from Trade When Firms Matter," Journal of Economic Perspectives, 26, 91-118.

Nelson, R. R. (1981): "Research on Productivity Growth and Productivity Differences: Dead Ends and New Departures," Journal of Economic Literature, 19, 1029-1064.

PAvitT, K. (1984): "Sectoral patterns of technical change: Towards a taxonomy and a theory," Research Policy, 13, 343-373.

Posner, M. V. (1961): "International trade and technical change," Oxford economic papers, 13, 323-341.

REINERT, E. S. (2009): "Emulation vs. comparative advantage: competing and complementary principles in the history of economic policy," in Industrial Policy and Development: The Political Economy of Capabilities Accumulation, ed. by M. Cimoli, G. Dosi, and J. E. Stiglitz, Oxford University Press.

Scellato, G. (2007): "Patents, firm size and financial constraints: an empirical analysis for a panel of Italian manufacturing firms," Cambridge Journal of Economics, 31, 55-76.

Serti, F., C. Tomasi, And A. Zanfei (2010): "Who Trades with Whom? Exploring the Links between Firms' International Activities, Skills, and Wages," Review of International Economics, 18, 951-971.

Sørensen, A. (2001): "Comparing apples to oranges: Productivity convergence and measurement across industries and countries: Comment," American Economic Review, 1160-1167.

Sterlacchini, A. (1999): "Do innovative activities matter to small firms in non-R\&Dintensive industries? An application to export performance," Research Policy, 28, 819832.

Syverson, C. (2011): "What Determines Productivity?" Journal of Economic Literature, 49, 326-65.

Van Beveren, I. and H. Vandenbussche (2010): "Product and process innovation and firms' decision to export," Journal of Economic Policy Reform, 13, 3-24. 
VERNON, R. (1966): "International investment and international trade in the product cycle," The Quarterly Journal of Economics, 80, 190-207.

Vivarelli, M., R. Evangelista, And M. Pianta (1996): "Innovation and employment in Italian manufacturing industry," Research policy, 25, 1013-1026.

Wakelin, K. (1998): "Innovation and export behaviour at the firm level," Research policy, 26, 829-841. 


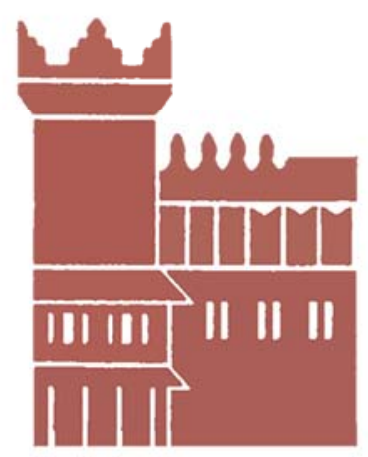

Alma Mater Studiorum - Università di Bologna DEPARTMENT OF ECONOMICS

Strada Maggiore 45

40125 Bologna - Italy

Tel. +39051 2092604

Fax +390512092664

http://www.dse.unibo.it 